\title{
STUDI TENTANG PELAKSANAAN MODEL PEMBELAJARAN INKUIRI PADA KOMUNITAS SEKOLAH RUMAH
}

\section{Ova Huzaefah}

\section{STKIP Arrahmaniyah}

\section{Sejarah Artikel}

Diterima 1 September 2017

Disetujui 1 Oktober 2017

Diterbitkan 1 Desember 2017

\section{Kata Kunci}

Komunitas Sekolah Rumah, Pendidikan Kesetaraan, Model Pembelajaran Inkuiri.

\begin{abstract}
Abstrak
Penelitian mengenai pelaksanaan model pembelajaran inkuiri di komunitas sekolah rumah ini bertujuan untuk menggambarkan pelaksanaan model pembelajaran inkuiri pada komunitas sekolah rumah sebagai model satuan pendidikan kesetaraan dan gambaran tentang praktik penerapan pembelajaran inkuiri pada tingkat satuan pendidikan. Subjek penelitian adalah komunitas sekolah rumah KerLiP. Hasil penelitian menunjukkan model pembelajaran inkuiri yang dilaksanakan oleh Komunitas Sekolah Rumah KerLiP (KSRK) merupakan model pembelajaran yang dikembangkan dari model pemrosesan informasi yang dikembangkan berdasarkan teori belajar kognitif (Piaget) dan model personal yang bertitik tolak dari teori humanistik. Dasar pengembangan model pembelajaran adalah kemandirian dan kemerdekaan siswa dalam pemenuhan rasa ingin tahu berbasiskan pemenuhan hak anak. Model Pembelajaran Inkuiri pada Komunitas Sekolah Rumah KerLiP diterapkan melalui pengelompokkan standar kompetensi lulusan (SKL) berdasarkan kelompok usia 6-9 tahun, 10-12 tahun dan 13-15 tahun. Model pembelajaran inkuiri pada Komunitas Sekolah Rumah KerLiP dikembangkan mekanisme bimbingan yang dilakukan oleh orangtua. Komunitas Sekolah Rumah KerLiP menyediakan program excellent parenting untuk membantu orang tua memahami tugas perkembangan anak sesuai dengan tingkat usia, tujuan pendidikan nasional, prinsip-prinsip penyelenggaraannya, model pengembangan pendidikan sesuai dengan falsafah khas keluarga. Komunitas Sekolah Rumah KerLiP menempatkan kemerdekaan dan kemandirian peserta didik (anak) sebagai hal yang utama dalam proses pembelajaran (pemenuhan rasa ingin tahu).
\end{abstract}

\section{Cara Mengutip}

Huzaefah, Ova. (2017). Studi tentang Pelaksanaan Model Pembelajaran Inkuiri pada Komunitas Sekolah Rumah. DWIJACENDEKIA Jurnal Riset Pedagogik, 1(2), 49-59.

Korespondensi Penulis: huzaefaho@gmail.com 


\section{PENDAHULUAN}

Pendidikan bertujuan mengembangkan potensi yang ada dalam diri manusia seluas-luasnya, sehingga hakikat dalam-dunia itu tersingkapkan. Ini berarti bukan hanya aspek kognitif informatif saja yang dikembangkan, tetapi juga moral, spiritual, kebudayaan dan penalaran sosial, serta tentu saja tidak kalah penting, afeksi. Suatu pendidikan dipandang bermutu diukur dari kedudukannya untuk ikut mencerdaskan kehidupan bangsa dan memajukan kebudayaan nasional adalah pendidikan yang berhasil mendidik generasi muda yang cerdas, berkarakter, bermoral, dan berkepribadian.

Dalam UU N0 20 tahun 2003 tentang Sistem Pendidikan Nasional BAB I ketentuan umum Bab VI mengenai Jalur, jenis dan jenjang pendidikan bahwa "Pendidikan dilaksanakan melalui tiga jalur dinyatakan yakni jalur pendidikan formal, non formal, dan in formal." Ini berarti bahwa keluarga merupakan wahana dan juga sekaligus sasaran pendidikan.

Sebagai wahana pendidikan, keluarga merupakan tempat terjadinya proses pendidikan anak dengan orangtua sebagai pendidik. Sedangkan sebagai sasaran pendidikan, Keluarga (dalam hal ini anggota-anggota keluarga) adalah merupakan sasaran didik dari program pendidikan keluarga (Family life education), dimana pendidikan keluarga dilakukan melalui jalur Pendidikan Non Formal. Menurut Soedijarto (1977:22) dalam naskah akademik PKBG (2004 : 24)

"Tantangan terbesar yang dihadapi dalam pembangunan Pendidikan Luar Sekolah termasuk program Pendidikan Keluarga pengelolaannya dirasakan kurang bersuasana akademik dan profesional."

Pendidikan kesetaraan merupakan pendidikan nonformal yang menyelenggarakan pendidikan umum mencakup program Paket A setara SD/MI, Paket B setara SMP/MTs, dan Paket C setara SMA/MA dengan penekanan pada penguasaan pengetahuan, keterampilan fungsional serta pengembangan sikap dan kepribadian profesional peserta didik. Pendidikan Kesetaraan memberikan perhatian khusus kepada mereka yang tinggal di daerah sulit, tertinggal, dan miskin, baik laki-laki maupun perempuan melalui diversifikasi layanan dan inovasi pembelajaran dengan model-model sebagai berikut :

1. Kelas Berjalan (Mobil , Kapal)

2. Tutor Kunjung (motor pembelajaran, perahu kelas)

3. Lumbung Belajar

4. Pembelajaran Berbasis TV

5. Pangkalan Belajar

6. Komunitas Belajar Mandiri dan/ Sekolah Rumah.

7. Multi-grade teaching

8. Sistem Modul, Tutorial, dan Belajar Mandiri

9. Pendidikan Kesetaraan on-line (Sekolah Maya)

(Direktorat Pendidikan Kesetaraan, 2007)

Dalam buku Sekolah Rumah Sebagai Satuan Pendidikan Kesetaraan yang diterbitkan oleh Direktorat Pendidikan Kesetaraan Dirjen Pendidikan Non Formal dan Informal Departemen Pendidikan Nasional Tahun 2007 disebutkan bahwa:

Sekolah rumah adalah proses layanan pendidikan yang secara sadar dan terarah dilakukan oleh orangtua/keluarga di rumah atau tempat-tempat lain dimana proses 
pembelajaran dapat berlangsung dalam suasana yang kondusif dengan tujuan agar setiap potensi anak yang unik dapat berkembang secara maksimal. (Direktorat Pendidikan Kesetaraan, 2007: 12)

Sekolah rumah berfungsi mengembangkan potensi peserta didik dengan penekanan pada penguasaan pengetahuan dan keterampilan fungsional serta pengembangan sikap dan kepribadian profesional, sekaligus memperluas akses terhadap pendidikan dasar dan menengah.

Tujuan diselenggarakannya sekolah rumah adalah untuk :

a. Menjamin penyelesaian pendidikan dasar dan menengah yang bermutu bagi peserta didik yang berasal dari keluarga yang menentukan pendidikan anaknya melalui sekolah rumah;

b. Menjamin pemenuhan kebutuhan belajar bagi semua manusia muda dan orang dewasa melalui akses yang adil pada programprogram belajar dan kecakapan hidup;

c. Menghapus disparitas gender dalam pendidikan dasar dan menengah; dan

d. Melayani peserta didik yang memerlukan pendidikan akademik dan kecakapan hidup secara fleksibel untuk meningkatkan mutu kehidupannya. (Direktorat Pendidikan Kesetaraan, 2007: 12 13)

Dalam praktek pelaksanaannya sekolah rumah dapat diklasifikasikan kedalam 3 (tiga) model sesuai dengan tujuan, kondisi dan kebutuhan masing-masing orangtua/keluarga. Model tersebut antara lain :

1. Sekolah rumah Tunggal
Dilaksanakan oleh orangtua dalam satu keluarga yang dalam melaksanakan kegiatan sekolah rumah untuk anak-anaknya, dengan sengaja tidak bergabung dengan keluarga lain yang menerapkan sekolah rumah tunggal lainnya;

2. Sekolah rumah Majemuk :

Dilaksanakan oleh orangtua dari dua atau lebih keluarga lain yang menerapkan sekolah rumah karena melakukan satu atau lebih kegiatan sementara kegiatan inti dan kegiatan lainnya tetap dilaksanakan dalam lingkungan rumah oleh orangtua masing-masing;

3. Komunitas Sekolah rumah :

Merupakan gabungan dari beberapa sekolah rumah majemuk yang menyusun dan menentukan silabus serta bahan ajar bagi anak-anak sekolah rumah, termasuk menentukan beberapa aktifitas dasar (olahraga, musik/seni dan bahasa) serta fasilitas tempat proses belajar mengajar dilaksanakan pada waktu tertentu. Berbeda dengan sekolah rumah tunggal dan majemuk maka komunitas sekolah rumah menyelenggarakan proses belajar dalam keluarga dengan komitmen orangtua dan komunitas dengan perbandingan tertentu 50 : $50 \%$. (Direktorat Pendidikan Kesetaraan, 2007: 15-16)

Komunitas sekolah rumah menentukan dan menyusun silabus serta bahan ajar bagi peserta didik termasuk menentukan beberapa aktivitas dasar serta fasilitas tempat tutorial dilaksanakan pada waktuwaktu yang disepakati. Komunitas sekolah rumah sebagai satuan pendidikan kesetaraan menjadi pilihan menarik dengan alasan-alasan berikut: 
1. Adanya kebutuhan-kebutuhan yang sama untuk menyelenggarakan pendidikan sebagai usaha sadar dan terencana dalam mewujudkan suasana belajar dan proses pembelajaran agar peserta didik secara aktif mengembangkan potensi dirinya untuk memiliki kekuatan spiritual keagamaan, pengendalian diri, kepribadian, kecerdasan, akhlak mulia, serta keterampilan yang diperlukan untuk dirinya, masyarakat, bangsa dan Negara.

2. Membangun fasilitas belajarmengajar yang lebih baik.

3. Ruang gerak sosialisasi semakin luas dalam batas-batas yang dapat dipantau.

4. Orangtua lebih banyak mendapatkan dukungan karena dapat menumbuhkan dialog saling belajar untuk bidang yang lebih dikuasai dan dapat memperdalam sesuai keahliannya

5. Format komunitas belajar biasanya sesuai untuk anak-anak usia 10 tahun keatas dengan kebutuhan belajar yang lebih banyak. (Direktorat Pendidikan Kesetaraan, 2007: 12-13)

Proses pembelajaran dalam sekolah rumah berbeda dengan di sekolah, diperlukan usaha yang maksimal untuk menyusun rancangan pembelajaran dan bahan ajar yang sesuai dengan kebutuhan peserta didik, falsafah khas keluarga, kondisi sosial, budaya dan lingkungan masyarakat setempat dan menempatkan orangtua sebagai pendidik utama. Model pembelajaran yang dapat menempatkan orang tua sebagai pendidik utama dalam konteks pelaksanaan pembelajaran yang berorientasi pada kepentingan terbaik anak untuk tumbuh kembang mandiri.

Memperhatikan berbagai kondisi yang telah diuraikan, sangat diperlukan pengembangan pengembangan model pembelajaran untuk bentukbentuk satuan pendidikan nonformal sebagai bagian dari upaya diversifikasi layanan dan inovasi pembelajaran.

Salah satu model pembelajaran yang mampu menggiatkan siswa untuk berpikir secara aktif dan kreatif di dalam proses pembelajaran adalah model pembelajaran inkuiri. Model pembelajaran inkuiri tidak hanya mengembangkan kemampuan intelektual tetapi seluruh potensi yang ada, termasuk pengembangan emosional dan pengembangan keterampilan.

Model inkuiri didefinisikan oleh Piaget (Sund dan Trowbridge, 1973) sebagai: Pembelajaran yang mempersiapkan situasi bagi anak untuk melakukan eksperimen sendiri; dalam arti luas ingin melihat apa yang terjadi, ingin melakukan sesuatu, ingin menggunakan simbol-simbol dan mencari jawaban atas pertanyaan sendiri, menghubungkan penemuan yang satu dengan penemuan yang lain, membandingkan apa yang ditemukan dengan yang ditemukan orang lain.

Kuslan Stone (Dahar,1991) mendefinisikan model inkuiri sebagai pengajaran di mana guru dan anak mempelajari peristiwa-peristiwa dan gejala-gejala ilmiah dengan pendekatan dan jiwa para ilmuwan. Pengajaran berdasarkan inkuiri adalah suatu strategi yang berpusat pada siswa di mana kelompokkelompok siswa dihadapkan pada suatu persoalan atau mencari 
jawaban terhadap pertanyaanpertanyaan di dalam suatu prosedur dan struktur kelompok yang digariskan secara jelas (Hamalik, 1991).

Wilson (Trowbridge, 1990) menyatakan bahwa model inkuiri adalah sebuah model proses pengajaran yang berdasarkan atas teori belajar dan perilaku. Inkuiri merupakan suatu cara mengajar murid-murid bagaimana belajar dengan menggunakan keterampilan, proses, sikap, dan pengetahuan berpikir rasional (Bruce \& Bruce, 1992). Senada dengan pendapat Bruce \& Bruce , Cleaf (1991) menyatakan bahwa inkuiri adalah salah satu strategi yang digunakan dalam kelas yang berorientasi proses. Inkuiri merupakan sebuah strategi pengajaran yang berpusat pada siswa, yang mendorong siswa untuk menyelidiki masalah dan menemukan informasi. Proses tersebut sama dengan prosedur yang digunakan oleh ilmuwan sosial yang menyelidiki masalah-masalah dan menemukan informasi.

Sementara itu, Trowbridge (1990) menjelaskan model inkuiri sebagai proses mendefinisikan dan menyelidiki masalah-masalah, merumuskan hipotesis, merancang eksperimen, menemukan data, dan menggambarkan kesimpulan masalah-masalah tersebut. Lebih lanjut, Trowbridge mengatakan bahwa esensi dari pengajaran inkuiri adalah menata lingkungan/suasana belajar yang berfokus pada siswa dengan memberikan bimbingan secukupnya dalam menemukan konsep-konsep dan prinsip-prinsip ilmiah.

Senada dengan pendapat Trowbridge, Amien (1987) dan Roestiyah (1998) mengatakan bahwa inkuiri adalah suatu perluasan proses diskoveri yang digunakan dalam cara yang lebih dewasa. Sebagai tambahan pada proses diskoveri, inkuiri mengandung proses mental yang lebih tinggi tingkatannya, misalnya merumuskan masalah, merancang eksperimen, melakukan eksperimen, mengumpulkan dan menganalisis data, menarik kesimpulan, menumbuhkan sikap objektif, jujur, hasrat ingin tahu, terbuka dan sebagainya.

Dapat disimpulkan bahwa inkuiri merupakan suatu proses yang ditempuh siswa untuk memecahkan masalah, merencanakan eksperimen, melakukan eksperimen, mengumpulkan dan menganalisis data, dan menarik kesimpulan. Jadi, dalam model inkuiri ini siswa terlibat secara mental maupun fisik untuk memecahkan suatu permasalahan. Dengan demikian, siswa akan terbiasa bersikap seperti para ilmuwan sains, yaitu teliti, tekun/ulet, objektif/jujur, kreatif, dan menghormati pendapat orang lain.

Sekolah rumah sebagai salah satu bentuk inovasi pembelajaran dalam pendidikan kesetaraan memliki keleluasaan dalam menentukan dan menyusun silabus serta bahan ajar bagi peserta didik termasuk menentukan beberapa aktivitas dasar serta fasilitas tempat tutorial dilaksanakan pada waktu-waktu yang disepakati. Hal tersebut membuat peneliti tertarik untuk melakukan kajian tentang bagaimana keluarga ataupun komunitas sekolah rumah melakukan pembelajaran. Lebih difokuskan lagi pada pelaksanaan model pembelajaran inkuiri yang 
dilakukan di Komunitas Sekolah Rumah KerLiP.

Penelitian ini dilakukan untuk menggambarkan pelaksanaan model pembelajaran inkuiri pada komunitas sekolah rumah sebagai model satuan pendidikan kesetaraan dan gambaran tentang praktik penerapan pembelajaran inkuiri pada tingkat satuan pendidikan.

Maka, dirumuskan hal yang akan diungkap dalam penelitian ini yaitu bagaimanakah pelaksanaan model pembelajaran inkuiri di komunitas sekolah rumah kerlip?

Berdasarkan fokus permasalahan di atas, maka dirumuskan pertanyaan penelitian sebagai berikut :
1. Bagaimana
perencanaan pembelajaran inkuiri di komunitas sekolah rumah kerlip?

2. Bagaimana langkah-langkah pembelajaran inkuiri di komunitas sekolah rumah kerlip?

3. Bagaimana evaluasi pembelajaran inkuiri yang dilakukan di komunitas Sekolah rumah KerLiP?

4. Apakah yang menjadi faktor pendukung dan penghambat dalam pelaksanaan pembelajaran inkuiri?

Tujuan umum penelitian ini adalah untuk mengetahui pelaksanaan model pembelajaran pada komunitas sekolah rumah sebagai model satuan pendidikan kesetaraan dan gambaran tentang praktik penerapan model pembelajaran pada tingkat satuan pendidikan.

Adapun tujuan khusus dengan dilaksanakannya penelitian ini, adalah untuk memperoleh gambaran tentang

1. Prosedur pembelajaran inkuiri di komunitas sekolah rumah KerLiP.

2. Perencanaan pembelajaran menggunakan model pembelajaran inkuiri di komunitas sekolah rumah KerLiP.

3. Pelaksanaan pembelajaran menggunakan model pembelajaran inkuiri di komunitas sekolah rumah KerLiP.

4. Evaluasi pembelajaran menggunakan model pembelajaran inkuiri di komunitas sekolah rumah KerLiP.

\section{PEMBAHASAN}

Model pembelajaran inkuiri yang dilaksanakan oleh Komunitas Sekolah Rumah KerLiP (KSRK) merupakan model pembelajaran yang dikembangkan dari Model Pemrosesan Informasi yang dikembangkan berdasarkan Teori Belajar Kognitif (Piaget) dan Model Personal yang bertitik tolak dari teori Humanistik.

Model Pemrosesan Informasi berorientasi pada kemampuan siswa memproses informasi yang dapat memperbaiki

kemampuannya. Pemrosesan informasi merujuk pada cara mengumpulkan/menerima stimuli dari lingkungan yaitu mengorganisasi data, memecahkan masalah, menemukan konsep dan menggunakan simbol verbal dan visual. Dipelopori oleh Robert Gagne (1985), bahwa pembelajaran merupakan faktor yang sangat penting dalam perkembangan yang merupakan hasil komulatif dari pembelajaran. Pembelajaran 
merupakan keluaran dari pemrosesan informasi yang berupa kecakapan manusia (human capibilities) yag terdiri dari: (1) informasi verbal, (2) kecakapan intelektual, (3) strategi kognitif, (4) sikap, dan (5) kecakapan motorik.

Sedangkan Model Personal berorientasi terhadap pengembangan diri individu. Perhatian utamanya pada emosional siswa untuk mengembangkan hubungan yang produktif dengan lingkungannya. Model ini menjadikan pribadi siswa yang mampu membentuk hubungan harmonis serta mampu memproses informasi secara efektif. Model ini juga berorientasi pada individu dan perkembangan keakuan. Menurut teori ini, pendidik harus berupaya menciptakan kondisi kelas yang kondusif, agar peserta didik merasa bebas dalam belajar dan mengembangkan dirinya, baik emosional maupun intelektual.

Yang menjadi dasar pengembangan model pembelajaran adalah kemandirian dan kemerdekaan siswa dalam pemenuhan rasa ingin tahu berbasiskan pemenuhan hak anak.

Model Pembelajaran Inkuiri pada Komunitas Sekolah Rumah KerLiP diterapkan melalui pengelompokkan standar kompetensi lulusan (SKL) berdasarkan kelompok usia 6-9 tahun, 10-12 tahun, dan 13-15 tahun.

Pendidik yang utama adalah orangtua, maka dalam model pembelajaran inkuiri pada Komunitas Sekolah Rumah KerLiP dikembangkan mekanisme bimbingan yang dilakukan oleh orangtua. Komunitas Sekolah Rumah KerLiP menyediakan program excellent parenting untuk membantu orang tua memahami tugas perkembangan anak sesuai dengan tingkat usia, tujuan pendidikan nasional, prinsip-prinsip penyelenggaraannya, model pengembangan pendidikan sesuai dengan falsafah khas keluarga dan dokumentasi perkembangan belajar anak-anak secara mandiri.

Komunitas Sekolah Rumah KerLiP menempatkan kemerdekaan dan kemandirian peserta didik (Anak) sebagai hal yang utama dalam proses pembelajaran (pemenuhan rasa ingin tahu). Hal ini bertujuan untuk menumbuhkan keingintahuan Anak, agar Anak berani berekspresi dan bereksplorasi secara leluasa, sehingga Anak akan tumbuh dengan penuh rasa percaya diri dan berkembang menjadi dirinya sendiri. Proses pembelajaran yang dilakukan adalah untuk memfasilitasi anak bagaimana cara belajar untuk memelihara kemandirian dengan memenuhi rasa ingin tahu dan memperluas jangkauannya seiring dengan tumbuh kembang anak.

Model pembelajaran inkuiri yang dilaksanakan oleh Komunitas Sekolah Rumah KerLiP mencakup :

1) Perencanaan pembelajaran di komunitas sekolah rumah kerlip

Menurut buku "Panduan Pengembangan Kurikulum Komunitas Sekolah Rumah KerLiP" dan "Naskah Akademik Pengembangan Pembejaran Komunitas Sekolah Rumah KerLiP”, perencanaan pembelajaran dalam komunitas sekolah rumah kerlip (KSRK) terdiri dari beberapa pengembangan beberapa komponen. Komponen tersebut adalah:
a. Deteksi Dini Kebutuhan Belajar
b. Pengembangan Silabus
c. Pengaturan Beban Belajar
d. Perumusan Ketuntasan Belajar 
e. Kalender Pendidikan

2) Pelaksanaan pembelajaran di komunitas sekolah rumah kerlip

a. Pengembangan Lembar Inspirasi Beragam Anak (LIBRA)

b. Cara Asyik Cari Tahu (CACT)

c. Mekanisme Bimbingan Belajar oleh orangtua dan/atau keluarga

d. Mekanisme bimbingan belajar oleh tutor

3) Evaluasi pembelajaran di komunitas Sekolah rumah KerLiP

a. Evaluasi hasil belajar peserta didik dilakukan oleh orang tua dan pendidik secara berkala untuk memantau proses, kemajuan, dan perbaikan hasil belajar peserta didik secara berkesinambungan.

b. Evaluasi peserta didik dan program pendidikan dilakukan oleh Litbang KerLiP secara berkala, menyeluruh, transparan, dan sistemik untuk menilai pencapaian standar kompetensi lulusan.

\section{SIMPULAN}

Komunitas sekolah rumah memiliki keunikan dalam pengelolaan pembelajaran, maka dilakukan penelitian mengenai pelaksanaan model pembelajaran inkuiri di komunitas sekolah rumah. Hasil penelitian menunjukkan model pembelajaran inkuiri yang dilaksanakan oleh Komunitas Sekolah Rumah KerLiP (KSRK) merupakan model pembelajaran yang dikembangkan dari model pemrosesan informasi yang dikembangkan berdasarkan teori belajar kognitif (Piaget) dan model personal yang bertitik tolak dari teori humanistik. Dasar pengembangan model pembelajaran adalah kemandirian dan kemerdekaan siswa dalam pemenuhan rasa ingin tahu berbasiskan pemenuhan hak anak. Model Pemrosesan Informasi berorientasi pada kemampuan siswa memproses informasi yang dapat memperbaiki kemampuannya.

Pemrosesan informasi merujuk pada cara mengumpulkan/menerima stimuli dari lingkungan yaitu mengorganisasi data, memecahkan masalah, menemukan konsep dan menggunakan simbol verbal dan visual. Dipelopori oleh Robert Gagne (1985), bahwa pembelajaran merupakan faktor yang sangat penting dalam perkembangan yang merupakan hasil komulatif dari pembelajaran. Pembelajaran merupakan keluaran dari pemrosesan informasi yang berupa kecakapan manusia (human capibilities) yag terdiri dari: (1) informasi verbal, (2) kecakapan intelektual, (3) strategi kognitif, (4) sikap, dan kecakapan motorik.

Sedangkan Model Personal berorientasi terhadap pengembangan diri individu. Perhatian utamanya pada emosional siswa untuk mengembangkan hubungan yang produktif dengan lingkungannya. Model ini menjadikan pribadi siswa yang mampu membentuk hubungan harmonis serta mampu memproses informasi secara efektif. Model ini juga berorientasi pada individu dan perkembangan keakuan. Menurut teori ini, pendidik harus berupaya menciptakan kondisi kelas yang kondusif, agar peserta didik merasa bebas dalam belajar dan 
mengembangkan dirinya, baik emosional maupun intelektual.

Model Pembelajaran Inkuiri pada Komunitas Sekolah Rumah KerLiP diterapkan melalui pengelompokkan standar kompetensi lulusan (SKL) berdasarkan kelompok usia 6-9 tahun, 10-12 tahun, dan 13-15 tahun. Model pembelajaran inkuiri pada Komunitas Sekolah Rumah KerLiP dikembangkan mekanisme bimbingan yang dilakukan oleh orangtua. Komunitas Sekolah Rumah KerLiP menyediakan program excellent parenting untuk membantu orang tua memahami tugas perkembangan anak sesuai dengan tingkat usia, tujuan pendidikan nasional, prinsip-prinsip penyelenggaraannya, model pengembangan pendidikan sesuai dengan falsafah khas keluarga. Komunitas Sekolah Rumah KerLiP menempatkan kemerdekaan dan kemandirian peserta didik (anak) sebagai hal yang utama dalam proses pembelajaran (pemenuhan rasa ingin tahu).

Adapun rekomendasi yang dapat diberikan oleh peneliti adalah sebagai berikut :

1. Semakin mempertajam konsep dan mengevaluasi prosedur penerapan model pembelajaran inkuiri agar dapat diterapkan lebih komperhensif pada satuan pendidikan lain sebagai upaya perluasan akses terhadap pendidikan

2. Melaksanakan pendidikan dan pelatihan bagi guru, baik secara mandiri maupun bekerja sama dengan pihak lain. Pendidikan dan pelatihan tersebut dilaksanakan sebagai upaya meningkatkan kompetensi yang dapat menunjang tugas-tugas guru, terutama yang berhubungan dengan pengembangan kurikulum serta inovasi pembelajaran.

3. Konsisten dalam memposisikan siswa sebagai poros utama kegiatan belajar, dimana siswa menjadi stake holder terpenting dalam pembelajaran.

4. Tetap konsisten dengan komitmen Komunitas Sekolah Rumah KerLiP yang berupaya menjadikan anak mandiri dan merdeka.

5. Memperbanyak riset dan dokumentasi kegiatan agar dapat lebih sempurna lagi mengembangkan pembelajaran, sehingga dapat memberikan pendidikan serta pengajaran yang lebih berkualitas bagi peserta didik. 


\section{DAFTAR PUSTAKA}

Alwasilah, A. Chaedar, 2003, Pokoknya Kualitatif: Dasar-Dasar Merancang dan Melakukan Penelitian Kualitatif, PT Dunia Pustaka Jaya kerjasama dengan Pusat Studi Sunda, Jakarta.

Baharudin, \& Esa Nur Wahyuni. 2007. Teori Belajar dan Pembelajaran. Yogyakarta: Ar-Ruzz Media.

B. Miles, Metthew. A. Michael Huberman.1992. Analisis Data Kualitatif. Jakarta: UI-press.

B. Sandjaja, Albertus Heriyanto. 2006.

Panduan Penelitian. Jakarta:

Prestasi.

Bruce, W.C. \& J.K. Bruce. 1992. Teaching With Inquiry. Maryland: Alpha Publishing Company.

Burden, P. R., \& Byrd, D. M. 1996. Method for effective teaching, second edition. Boston: Allyn and Bacon.

Cleaf, D.W.V. 1991. Action In Elementary Social Studies. Singapore: Allyn and Bacon.

Dahar, Ratna Wilis. 1991. Teori-Teori Belajar. Jakarta: Penerbit Erlangga.

Departemen Pendidikan Nasional. 2004. Naskah Akademik Pendidikan Keluarga Berwawasan Gender (PKBG). Jakarta: Proyek Peningkatan Peran Masyarakat dan Pemampuan Kelembagaan Pengarusutamaan Gender.

Direktorat Pendidikan Kesetaraan. 2007. Komunitas Sekolahrumah Sebagai Satuan Pendidikan Kesetaraan. Jakarta: Direktorat Pendidikan Kesetaraan, Direktorat Jenderal Pendidikan Non Formal dan Informal, Departemen Pendidikan Nasional.
Faisal, Sanapiah. 2003. Format-format Penelitian Sosial, Dasar-dasar dan Aplikasi. Jakarta: RajaGrafindo Persada.

Gagne,Briggs dan Wager. 1992. Principle of Instructional Design Second Edition. Holt, Rinehart and Winston; New York

Gulo, W. (2008). Strategi BelajarMengajar. Jakarta: Gramedia Widiaswara

Gunter, M., et al. 1990. Instruction: A Models Approach. Boston: MA: Allyn \& Bacon.

Hamalik, Oemar. 2013. Proses Belajar Mengajar. Jakarta : PT.Bumi Aksara.

Hasan, Said Hamid, dkk, 2010. Pengembangan Pendidikan Budaya dan Karakter Bangsa. Jakarta: Kementrian Pendidikan Nasional Badan Penelitian dan Pengembangan Pusat Kurikulum.

Jerome S. Bruner (1960) Journal of Child Psychology and Psychiatry Volume 17, Issue 2, pages 89100, April 1976. Diakses tanggal 17 Januari 2012.

Johnson, Elaine B. 2009. Contextual Teaching and Learning Menjadikan Kegiatan BelajarMengajar Mengasyikan dan Bermakna. Bandung: MLC

Joyce B. 1992. Model of Teaching $7^{\text {th }}$ Ed. Boston: Allyn and Bacon

Kourilsky, Marilynd and Quaranta, Lory. 1987. Effective Teaching. London: Scott Poresman Company

Kuntowijoyo. 1994. Metodologi Sejarah. Yogyakarta : PT. Tiara Wacana.

Lexy J. Moleong. 2005. Metodologi Penelitian Kualitatif. Bandung: Rosdakarya. 
Malo, Sri Tresnaningtyas, Gulardi. 1986. Metode Penelitian

Masyarakat. Jakarta: Pusat Antar IImu-ilmu Sosial UI

Margono. 1996. Metodologi Penelitian Pendidikan. Jakarta: Rineka Cipta.

Moore, Nick. 1995. Cara Meneliti. Bandung: ITB Bandung.

Roestiyah, N.K. (1998). Strategi Belajar Mengajar. Jakarta: PT. Rineka Cipta.

Sagala, Syaiful. 2003. Konsep dan Makna Pembelajaran. Bandung: Penerbit Alfabeta.

Salim, Agus. 2006. Teori \& Paradigma Penelitian Sosial. Yogyakarta: Tiara Wacana.

Sapriya. 2000. Studi Sosial Konsep dan Model Pembelajaran. Bandung: Rindi Press

Sudjana, 2001, Metode Statistika, Edisi Revisi, Cet. 6, Bandung: Tarsito.
Sukmadinata, Nana Syaodih. 2004. Landasan Psikologi Proses Pendidikan. Bandung: PT remaja Rosdakarya.

Sugiyono. 2009. Metode Penelitian Pendidikan Pendekatan Kuantitatif, Kualitatif, dan R \& D. Bandung: Alfabeta.

Sugiyono. (2012). Memahami Penelitian Kualitatif. Bandung: Alfabeta

Sund, Robert B. \& Leslie W. Trowbridge.1973. Teaching Science By Inquiry in The Secondary School. Second edition. London: Charles E. Merrill Publishing Company.

Trowbridge \& Bybee. 1990. Becoming a Secondary School Science Teacher. Ohio: Merill Publising

Tim Penelitian dan Pengembangan KerLiP. 2007. Pengembangan Kurikulum Komunitas Sekolah Rumah KerLiP. Bandung: Perkumpulan KerLiP 